\title{
Iodine-Catalyzed Microwave-Induced Multicomponent Aza-Diels Alder [4+2] Cycloaddition Reaction: A Versatile Approach Towards Bicyclo- $[2,2,2]$-Octanones
}

\author{
Ram Naresh Yadav ${ }^{1,2}$, Ashwini Bobbala ${ }^{1}$ and Bimal K Banik ${ }^{1,3^{*}}$ \\ ${ }^{1}$ Department of Chemistry, The University of Texas-Pan American, 1201 West University Drive, Edinburg, TX 78539, USA \\ ${ }^{2}$ Department of Chemistry, Faculty of Engineering and Technology, Veer Bahadur Singh Purvanchal University, Jaunpur, Uttar Pradesh, India \\ ${ }^{3}$ Community Health Systems of South Texas, Edinburg, Texas 78539, USA
}

*Corresponding author: Banik BK, Department of Chemistry, The University of Texas-Pan American, 1201 West University Drive, Edinburg, TX 78539, USA, Tel: 09566658741; E-mail: bimalbanik10@gmail.com

Rec date: April 04, 2018; Acc date: April 16, 2018; Pub date: April 26, 2018

Copyright: (C) 2018 Yadav RN, et al. This is an open-access article distributed under the terms of the Creative Commons Attribution License, which permits unrestricted use, distribution, and reproduction in any medium, provided the original author and source are credited.

\author{
Abstract \\ Molecular iodine-catalyzed microwave-assisted one-pot three components aza-Diels-Alder reaction has been \\ investigated. This method has been used for an efficient synthesis of 2-azabicyclo-[2, 2, 2]-cyclooctanones.
}

Keywords: Aza-diels-alder; Microwave chemistry; Azabicycle; KetoEnol tautomerization; Alkaloids

\section{Introduction}

The Aza-Diels-Alder reaction has served as one of the most promising tools for the synthesis of bicyclic nitrogen-containing heterocyclic scaffolds of naturally occurring biologically active products [1-12]. The reaction of various aromatic amines, aldehydes and enones provides a viable route for the synthesis of bicycle-[2,2,2]octanes in the presence of specific catalyst. This ring has serve as an important precursor for natural product synthesis and has immense synthetic applications. The 2 -azabicyclo-[2,2,2]-octane skeleton is found in a variety of natural products, particularly the Iboga family of alkaloids $[13,14]$. The imine derived in situ acts as a dienophile in this reaction. The application of various Lewis and Bronsted acids has been well documented in the literature to promote this reaction. However, many Lewis acids are not environmentally benign and are corrosive in nature. Imines are also not well tolerated in presence of these acidic conditions.

In connection with our studies on molecular iodine-catalyzed reactions, we describe herein a versatile method for the synthesis of various bicyclic nitrogen-containing heterocycles by a three component aza-Diels-Alder reaction [15-24].

\section{Experimental Section}

\section{General}

Melting points were determined in a Fisher Scientific electrochemical Mel-Temp ${ }^{*}$ manual melting point apparatus (Model 1001) equipped with a $300^{\circ} \mathrm{C}$ thermometer. FT-IR spectra were recorded on a Bruker Alpha Modular Platinum-ATR FT-IR spectrometer with OPUS software, using the samples directly (neat) without making pallets. 1H-NMR $(600 \mathrm{MHz})$ and 13C-NMR $(150$ $\mathrm{MHz}$ ) spectra were obtained at room temperature with Bruker superconducting UltrashieldTM Plus $600 \mathrm{MHz}$ NMR spectrometer with central field 14.09 Tesla, coil inductance 89.1 Henry and magnetic energy $1127.2 \mathrm{~kJ}$ using $\mathrm{CDCl}_{3}$ as solvent. Iodine (reagent grade,) 98\%) purchased from Sigma-Aldrich Corporation was used. All other chemicals were purchased from Sigma-Aldrich Corporation (analytical grade). Throughout the project solvents were purchased from FisherScientific. Deionized water was used for the preparation of all aqueous solutions. The spectral data for the few of endo adducts are as follows:

2, 3- Diphenyl-2-azabicyclo[2.2.2] octane-5-one(4a): ${ }^{1} \mathrm{H}-\mathrm{NMR}(600$ $\left.\mathrm{MHz} \mathrm{CDCl}_{3}\right) \delta$ 7.35-7.30 (2 H, m), 7.24-7.20 $(2 \mathrm{H}, \mathrm{m}), 7.20-7.10(2 \mathrm{H}$, m), 6.65-6.63 (2 H, m), 6.53-6.52 (2 H, m), $4.71(1 \mathrm{H}, \mathrm{d}, \mathrm{J}=2.3 \mathrm{~Hz}), 4.48$ $(1 \mathrm{H}, \mathrm{t}, \mathrm{J}=3.1 \mathrm{~Hz}), 2.63(1 \mathrm{H}, \mathrm{q}, \mathrm{J}=3.0 \mathrm{~Hz}), 2.34(1 \mathrm{H}, \mathrm{dd}, \mathrm{J}=1.8,18.7$ $\mathrm{Hz}), 2.19-2.18(1 \mathrm{H}, \mathrm{m}), 1.84-1.83(1 \mathrm{H}, \mathrm{m}), 1.65-1.49(2 \mathrm{H}, \mathrm{m}) ;{ }^{13} \mathrm{C}-$ NMR $\left(150 \mathrm{MHz}, \mathrm{CDCl}_{3}\right) \delta 16.4\left(\mathrm{CH}_{2}\right), 26.0\left(\mathrm{CH}_{2}\right), 42.3\left(\mathrm{CH}_{2}\right), 48.2$ $(\mathrm{CH}), 51.0(\mathrm{CH}), 62.4(\mathrm{CH}), 113.1(\mathrm{CH}), 117.7(\mathrm{CH}), 126.2(2 \mathrm{CH})$, $127.4(2 \mathrm{CH}), 128.4(2 \mathrm{CH}), 129.3(2 \mathrm{CH}), 140.1(\mathrm{C}), 148.2(\mathrm{C}), 213.6$ (C).

2-(4-methoxyphenyl)-3-phenyl-2-azabicyclo[2.2.2]octan-5-one (4b): ${ }^{1} \mathrm{H}-\mathrm{NMR}\left(600 \mathrm{MHz}, \mathrm{CDCl}_{3}\right) \delta$ 7.36-7.19 $(5 \mathrm{H}, \mathrm{m}), 6.67-6.65(2 \mathrm{H}$, m), 6.49-6.46 (2 H, m), $4.63(1 \mathrm{H}, \mathrm{d}, \mathrm{J}=1.7 \mathrm{~Hz}), 4.37-4.36(1 \mathrm{H}, \mathrm{m}), 3.62$ $(3 \mathrm{H}, \mathrm{s}), 2.70(1 \mathrm{H}, \mathrm{qt}, \mathrm{J}=2.9 \mathrm{~Hz}), 2.30(1 \mathrm{H}, \mathrm{dd}, \mathrm{J}=1.8 \mathrm{~Hz}, 16.7 \mathrm{~Hz})$, 2.23-2.10 (1 H, m), 1.84-1.78 (1 H, m), 1.78-1.53 (1 H, m); ${ }^{13} \mathrm{C}-\mathrm{NMR}$ $\left(150 \mathrm{MHz}, \mathrm{CDCl}_{3}\right) \delta 16.3\left(\mathrm{CH}_{2}\right), 26.3\left(\mathrm{CH}_{2}\right), 41.9\left(\mathrm{CH}_{2}\right), 48.9(\mathrm{CH})$, $51.1(\mathrm{CH}), 55.6\left(\mathrm{OCH}_{3}\right), 62.7\left(\mathrm{CH}_{3}\right), 114.3(\mathrm{CH}), 114.8(2 \mathrm{CH}), 126.2$ $(2 \mathrm{CH}), 127.3(2 \mathrm{CH}), 128.8(2 \mathrm{CH}), 140.4(\mathrm{C}), 142.7(\mathrm{C}), 52.2(\mathrm{C})$, 213.9 (C).

3-(4-flurophenyl)-2-(4 methoxyphenyl)-2-azabicyclo[2.2.2]octan-5one (4c): ${ }^{1} \mathrm{H}-\mathrm{NMR}\left(600 \mathrm{MHz}, \mathrm{CDCl}_{3}\right) \delta$ 7.32-7.30 $(2 \mathrm{H}, \mathrm{m}), 7.01-6.97$ $(2 \mathrm{H}, \mathrm{m}), 6.67-6.65(2 \mathrm{H}, \mathrm{m}), 6.64(2 \mathrm{H}, \mathrm{m}) 4.61(1 \mathrm{H}, \mathrm{brs}) 2.69(3 \mathrm{H}, \mathrm{s})$, 2.69-2.65 (2 H, m), 2.55-2.53 (1 H, m), $2.50(1 \mathrm{H}, \mathrm{dd}, \mathrm{J}=1.8,18.7 \mathrm{~Hz})$, 2.19-2.13 (1 H, m), 1.84-1.79 (1 H, m), 1.66-1.55 (1 H, m); ${ }^{13} \mathrm{C}-\mathrm{NMR}$ $\left(150 \mathrm{MHz}, \mathrm{CDCl}_{3}\right) \delta 16.3\left(\mathrm{CH}_{2}\right), 6.4\left(\mathrm{CH}_{2}\right), 41.9\left(\mathrm{CH}_{2}\right), 49.1(\mathrm{CH})$, $51.1(\mathrm{CH}), 55.6(\mathrm{OCH} 3), 62.1(\mathrm{CH}), 114.4(\mathrm{CH}), 114.9(\mathrm{CH}), 115.6$ $(\mathrm{CH}), 115.6), 115.8(\mathrm{CH}), 127.8(2 \mathrm{CH}), 127.9(2 \mathrm{CH}), 142.5(\mathrm{C}), 152.2$ (C), $161.3(\mathrm{C}), 163.0(\mathrm{C}), 214.0(\mathrm{C})$.

2-(4-methoxyphenyl)-3-(p-tolyl)-2-azabicyclo[2.2.2]octan-5one(4d): ${ }^{1} \mathrm{H}-\mathrm{NMR}\left(600 \mathrm{MHz}, \mathrm{CDCl}_{3}\right) \delta$ 7.23-7.22 (2 H, m), 7.11-7.10 
Citation: Yadav RN, Bobbala A, Banik BK (2018) lodine-Catalyzed Microwave-Induced Multicomponent Aza-Diels Alder [4+2] Cycloaddition Reaction: A Versatile Approach Towards Bicyclo-[2,2,2]-Octanones. Mod Chem Appl 6: 253. doi:10.4172/2329-6798.1000253

Page 2 of 4

( $2 \mathrm{H}, \mathrm{m}), 6.67-6.65(2 \mathrm{H}, \mathrm{m}), 6.49-6.47(2 \mathrm{H}, \mathrm{m}), 4.59$ (1 H, brs), 4.35 $(1 \mathrm{H}, \mathrm{t}, \mathrm{J}=2.3 \mathrm{~Hz}), 3.62(3 \mathrm{H}, \mathrm{s}), 2.68(1 \mathrm{H}, \mathrm{t}, \mathrm{J}=3.1 \mathrm{~Hz}), 2.65(1 \mathrm{H}, \mathrm{t}$, $\mathrm{J}=3.1 \mathrm{~Hz}), 2.55(1 \mathrm{H}, \mathrm{q}, \mathrm{J}=2.9 \mathrm{~Hz}), 2.31(1 \mathrm{H}, \mathrm{d}, \mathrm{J}=1.7 \mathrm{~Hz}), 2.28(3 \mathrm{H}, \mathrm{s})$, 2.21-2.15 (1 H, m), 1.82-1.77 (1 H, m), 1.69-1.64 (1 H, m); ${ }^{13} \mathrm{C}-\mathrm{NMR}$ $\left(150 \mathrm{MHz}, \mathrm{CDCl}_{3}\right) \delta 16.4\left(\mathrm{CH}_{2}\right), 21.1\left(\mathrm{CH}_{3}\right), 26.3\left(\mathrm{CH}_{2}\right), 41.9\left(\mathrm{CH}_{2}\right)$, $48.9(\mathrm{CH}), 51.2(\mathrm{CH}), 55.7\left(\mathrm{OCH}_{3}\right), 62.5(\mathrm{CH}), 114.3(2 \mathrm{CH}), 114.8(2$ $\mathrm{CH}), 126.2(2 \mathrm{CH}), 129.5(2 \mathrm{CH}), 137.0(\mathrm{C}), 137.0(\mathrm{C}), 142.8(\mathrm{C}), 152.0$ (C), $214.1(\mathrm{C})$.

\section{Results and Discussion}

At the beginning of this investigation, we attempted to optimize the conditions for the aza-Diels-Alder reaction using aromatic aldehydes
(1), amines (2) and cyclohexenone (3) in various solvents under conventional heating. The reaction of equimolar proportion of aniline (1 mmol), benzaldehyde $(1 \mathrm{mmol})$ and cyclohexenone $(1 \mathrm{mmol})$ was investigated in the presence of $10 \mathrm{~mol} \%$ of molecular iodine in different solvents; e.g., THF, DCM, Ethanol, Toluene, Benzene, and DME with various rage of temperature (Scheme 1, Table 1).

\begin{tabular}{|l|l|l|l|l|}
\hline Entry & Solvent (s) & Temperature $\left({ }^{\circ} \mathbf{C}\right)$ & Method (s) & Yield (s) \\
\hline 1 & Ethanol & $65-70$ & Conventional heating & 0 \\
\hline 2 & Methanol & $55-65$ & Conventional heating & 0 \\
\hline 3 & Dichloromethane & $35-40$ & Conventional heating & 0 \\
\hline 4 & Benzene & $75-80$ & Conventional heating & Trace \\
\hline 5 & Toluene & $100-110$ & Dean Stark & 10 \\
\hline 6 & Xylene & $100-140$ & Dean Stark & 10 \\
\hline 7 & Dimethyl Formamide & $100-140$ & Conventional heating & 20 \\
\hline
\end{tabular}

Table 1: Solvent optimization for [4+2] Aza-Diels-Alder reaction under conventional thermal condition.

The reaction does not proceed well under these conditions. Either decomposition or charring of the starting materials was observed. Under these conditions, a very poor reaction occurred in DMF, xylene and toluene. The reaction was conducted without iodine and as usual, no desired products were formed. However, microwave-induced reaction of the same reaction mixtures in DMF and in the presence of
$10 \mathrm{~mol} \%$ of molecular iodine gave products with high stereochemical control of diastereoselectivity (endo-exo ratio) in reasonably good yield [25-32]. After the realization of successful reaction conditions, this method was extended to various aromatic aldehydes, amines, and cyclohexenone in order to synthesize 2,3-diaryl- substituted nitrogencontaining bicyclic compounds.<smiles>[R2]c1ccc(C=O)c([R])c1</smiles>

1<smiles>[R3]c1ccc(N)cc1</smiles>

3

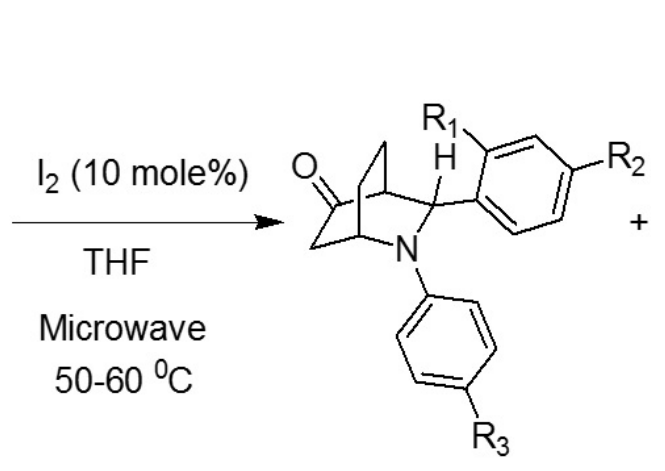

4<smiles>[R]c1ccc(N2C3CC(=O)CC(C3)[C@H]2c2ccc([R3])cc2[R2])cc1</smiles>

5

Scheme 1: One-pot three-component microwave-induced molecular iodine-catalyzed Aza-Diels-Alder Reaction.

The results in Table 2 indicate that the reaction with monocyclic amines affords the endo adduct as the major product. The yield of the products was mainly dependant on the groups present in the aromatic systems. The inductive effects ( $+\mathrm{I}$ and $-\mathrm{I}$ effects) and the size of the groups influenced the ratio of the products. Electron-donating groups (for example, methoxy and methyl) at the para-position of the aromatic ring of aldehydes and amines favored the formation of the endo products.

Molecular iodine is an environmentally benign and very economical catalyst and possesses diverse catalytic activities in the field of organic synthesis. 
Citation: Yadav RN, Bobbala A, Banik BK (2018) lodine-Catalyzed Microwave-Induced Multicomponent Aza-Diels Alder [4+2] Cycloaddition Reaction: A Versatile Approach Towards Bicyclo-[2,2,2]-Octanones. Mod Chem Appl 6: 253. doi:10.4172/2329-6798.1000253

Page 3 of 4

Iodine has a strong ability to co-ordinate with the oxygen atoms of the cyclic enones and this process accelerates the keto-enol tautomerization. This process is obligated to shift the equilibrium toward the enol side (cyclohexadienolate) which acts as the diene component in the reaction. Aldimines works as the dienophile. The reaction between this diene and dienophile gives the product. In a representative procedure, benzaldehyde $(1 \mathrm{mmol})$, aniline $(1 \mathrm{mmol})$ and cyclohexenone $(1 \mathrm{mmol})$ in $\operatorname{DMF}(2 \mathrm{~mL})$ were taken in a microwave vial and $10 \mathrm{~mol} \%$ of molecular iodine was added. The vial was placed in microwave reactor and irradiated at $300 \mathrm{~W}$ at $60^{\circ} \mathrm{C}$. The reaction preceded well and produced the product in good yield. The imines were formed in the reaction mixture from the reaction of monocyclic aromatic aldehydes and primary aromatic amines. The ratio of the products was calculated from the ${ }^{1} \mathrm{H}$ NMR spectrum of the crude reaction mixture after extraction. The isomeric compounds were purified by column chromatography over silica gel. The structures of the desired products were confirmed on the basis of spectroscopic $\left({ }^{1} \mathrm{H}\right.$ NMR, ${ }^{13} \mathrm{C}$ NMR, DEPT NMR, and IR) data of the pure compounds.

\begin{tabular}{|c|c|c|c|c|c|c|c|c|}
\hline \multirow[t]{2}{*}{ S.N. } & \multicolumn{2}{|c|}{ Aldehyde } & \multirow{2}{*}{$\begin{array}{l}\text { Amine } \\
\text { R3 }\end{array}$} & \multirow[t]{2}{*}{$4 / 5\left(\right.$ endo/exo) $^{a}$} & \multirow[t]{2}{*}{ Time (min) } & \multirow[t]{2}{*}{ Solvent } & \multirow[t]{2}{*}{ Temperature } & \multirow[t]{2}{*}{ Yield $^{b}(\%)$} \\
\hline & R1 & R2 & & & & & & \\
\hline 1 & $\mathrm{H}$ & $\mathrm{H}$ & $\mathrm{H}$ & $60 / 40$ & 35 & THF & 50 & 90 \\
\hline 2 & $\mathrm{H}$ & $\mathrm{H}$ & OMe & $80 / 20$ & 35 & THF & 45 & 78 \\
\hline 3 & $\mathrm{~F}$ & $\mathrm{H}$ & $\mathrm{OMe}$ & $90 / 10$ & 40 & DCM & 30 & 80 \\
\hline 4 & $\mathrm{CH}_{3}$ & $\mathrm{H}$ & $\mathrm{OMe}$ & $70 / 30$ & 40 & DCM & 30 & 80 \\
\hline 5 & $\mathrm{OMe}$ & $\mathrm{OMe}$ & $\mathrm{OMe}$ & $70 / 30$ & 50 & THF & 55 & 80 \\
\hline 6 & $\mathrm{H}$ & $\mathrm{H}$ & $\mathrm{CH}_{3}$ & $75 / 25$ & 25 & THF & 60 & 85 \\
\hline 7 & $\mathrm{CH}_{3}$ & $\mathrm{CH} 3$ & $2 \mathrm{OMe}$ & $65 / 35$ & 40 & THF & 45 & 82 \\
\hline
\end{tabular}

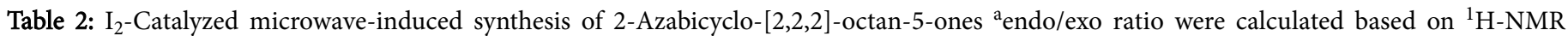
spectra of the crude reaction mixtures. ${ }^{\text {isolated yield. }}$

\section{Conclusion}

In conclusion, we have identified molecular iodine-catalyzed microwave-mediated one-pot three component aza-Diels-Alder

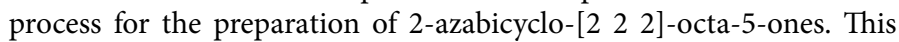
reaction is simple and important products are obtained within a very short time.

\section{Acknowledgements}

BKB gratefully acknowledges the funding support from Kleberg Foundation of Texas.

\section{References}

1. Hadden $\mathrm{M}$, Nieuwenhuyzen $\mathrm{M}$, Potts D, Stevenson PJ, Thompson N (2001) Synthesis and reactivity of hexahydropyrroloquinolines. Tetrahedron 57: 5615-5624.

2. Hoemann MZ, Xie RL, Rossi RF, Meyer S, Sidhu A, et al. (2002) Potent in vitro methicillin-resistant Staphylococcus aureus activity of $2-(1 \mathrm{H}-$ indol-3-yl) tetrahydroquinoline derivatives. Bioorg Med Chem Lett 12: 129-132.

3. Cheng D, Zhou J, Saiah E, Beaton G (2002) Ketene dithioacetals in the aza-Diels- Alder reaction with $\mathrm{N}$-arylimines: A versatile approach to tetrahydroquinolines, 2, 3-dihydro-4-quinolones, and 4-quinolones. Organic Letters 4: 4411-4414.

4. Nagarajan R, Perumal PT (2002) InCl3 and In (OTf) 3 catalyzed reactions: Synthesis of 3-acetyl indoles, bis-indolylmethane and indolylquinoline derivatives. Tetrahedron 58: 1229-1232.

5. Yadav JS, Reddy BV, Rao RS, Kumar SK, Kunwar AC (2002) InCl3Catalyzed hetero-Diels-Alder reaction: an expeditious synthesis of pyranoquinolines. Tetrahedron 58: 7891-7896.

6. Sabitha G, Reddy EV, Yadav JS, Krishna KR, Sankar AR (2002) Stereoselective synthesis of octahydro-3bH-[1,3] dioxolo [4 ", 5 ": 4', 5'] furo $\left[2^{\prime}, 3^{\prime}: 5,6\right]$ pyrano [4, 3-b] quinolines via intramolecular heteroDiels-Alder reactions catalyzed by bismuth (III) chloride. Tetrahedron Lett 43: 4029-4032.

7. Powell DA, Batey RA (2003) Lanthanide (III)-catalyzed multi-component aza-Diels-Alder reaction of aliphatic N-arylaldimines with cyclopentadiene. Tetrahedron Lett 44: 7569-7573.

8. Shi M, Shao LX, Xu B (2003) The Lewis acids catalyzed aza-Diels- Alder reaction of methylenecyclopropanes with imines. Organic Letters 5: 579-582.

9. Lavilla R, Bernabeu MC, Carranco I, Díaz JL (2003) Dihydropyridinebased multicomponent reactions. Efficient entry into new tetrahydroquinoline systems through Lewis acid-catalyzed formal [4+2] cycloadditions. Organic Letters 5: 717-720.

10. Fadel F, Titouani SL, Soufiaoui M, Ajamay H, Mazzah A (2004) Synthèse de nouveaux dérivés tétrahydroquinoléines et quinoléines via la réaction d'aza-Diels-Alder suivie d'aromatisation. Tetrahedron Letters 45: 5905-5908.

11. Hermitage S, Howard JA, Jay D, Pritchard RG, Probert MR, et al. (2004) Mechanistic studies on the formal aza-Diels-Alder reactions of $\mathrm{N}$-aryl imines: evidence for the non-concertedness under Lewis-acid catalysed conditions. Org Biomol Chem 2: 2451-2460.

12. Carranco I, Díaz JL, Jiménez O, Vendrell M, Albericio F, et al. (2005) Multicomponent reactions with dihydroazines: efficient synthesis of a diverse set of pyrido-fused tetrahydroquinolines. J Comb Chem 7: 33-41.

13. Sundberg RJ, Smith SQ (2002) The IBOGA alkaloids and their role as precursors of anti-neoplastic bisindole catharanthus alkaloids. The Alkaloids 59: 281-386.

14. Jana GK, Paul S, Sinha S (2011) Progress in the synthesis of ibogaalkaloids and their congeners. Org Prep Proced Int 43: 541-573.

15. Samajdar S, Basu MK, Becker FF, Banik BK (2001) A new molecular iodine-catalyzed thioketalization of carbonyl compounds: Selectivity and scope. Tetrahedron Lett 42: 4425-4427.

16. Basu MK, Samajdar S, Becker FF, Banik BK (2002) A New Molecular Iodine-Catalyzed Acetalization of Carbonyl Compounds. Chem Inform, 33 . 
Citation: Yadav RN, Bobbala A, Banik BK (2018) lodine-Catalyzed Microwave-Induced Multicomponent Aza-Diels Alder [4+2] Cycloaddition Reaction: A Versatile Approach Towards Bicyclo-[2,2,2]-Octanones. Mod Chem Appl 6: 253. doi:10.4172/2329-6798.1000253

Page 4 of 4

17. Banik BK, Samajdar S, Banik I (2004) Simple synthesis of substituted pyrroles. J Org Chem 69: 213-216.

18. Banik BK, Chapa M, Marquez J, Cardona M (2005) A remarkable iodinecatalyzed protection of carbonyl compounds. Tetrahedron Lett 46: 2341-2343.

19. Banik BK, Fernandez M, Alvarez C (2005) Iodine-catalyzed highly efficient Michael reaction of indoles under solvent-free condition. Tetrahedron Lett 46: 2479-2482.

20. Banik BK, Garza R (2007) Molecular iodine-catalyzed deprotection of acetals and ketals in acetone. Chem Edu 12: 75-76.

21. Banik BK, Garcia I, Morales FR, Aguilar C (2007) Novel synthesis of substituted pyrrole bound to indolinone via molecular iodine-catalyzed reaction. Heterocyclic Commun 13: 109-112.

22. Banik I, Samajdar S, Basu MK, Banik BK (2011) Heterocyclic Letters, pp: 111-118.

23. Banik BK, Manhas MD (2012) Tetrahedron Symposium in Print 68 10769-10779

24. Bandyopadhyay D, Cruz J, Yadav RN, Banik BK (2012) An expeditious iodine-catalyzed synthesis of 3-pyrrole-substituted 2-azetidinones. Molecules 17: 11570-11584
25. Banik BK, Aguilar H, Cordova D (2008) Heterocycles 11: 2321-2329.

26. Kall A, Bandyopadhyay D, Banik BK (2010) Microwave-induced azaMichael reaction in water: A remarkably simple procedure. Synthetic Communications 40: 1730-1735.

27. Ramos K, Banik BK (2011) Microwave-Induced Clay-Mediated Preparation of Imines: One-Pot Synthesis of $\beta$-Lactams. Heterocyclic, pp: 27-30.

28. Banik I, Becker FF, Banik BK (2011) Heterocyclic Lett, pp: 55-57.

29. Bandyopadhyay D, Yanez MA, Banik BK (2011) Heterocyclic Lett, 65.

30. Bandyopadhyay D, Mukherjee S, Banik BK (2010) An expeditious synthesis of $\mathrm{N}$-substituted pyrroles via microwave-induced iodinecatalyzed reactions under solventless conditions. Molecules 15: 2520-2525.

31. Bandyopadhyay D, Mukherjee S, Rodriguez RR, Banik BK (2010) An effective microwave-induced iodine-catalyzed method for the synthesis of quinoxalines via condensation of 1,2-diamines with 1, 2-dicarbonyl compounds. Molecules 15: 4207-4212.

32. Bandyopadhyay D, Cruz J, Banik BK (2012) Tetrahedron Symposium in Print 68: 10686-10695. 